\title{
Brain and Behavior: On the Perspective of Miguel Covian and César Timo-laria ${ }^{1}$
}

\author{
Cérebro e Comportamento: A Perspectiva de Miguel Covian e César Timo-laria \\ Cerebro y Comportamiento: La Perspectiva de Miguel Covian y César Timo-laria
}

\author{
Rodrigo Lopes Miranda ${ }^{2}$ \\ Universidade Católica Dom Bosco (UCDB) \\ Marina Massimi \\ Anette Hoffmann \\ Universidade de São Paulo (USP) \\ Sérgio Dias Cirino \\ Universidade Federal de Minas Gerais (UFMG)
}

\begin{abstract}
Historical studies of neuroscience in Brazil have focused on many aspects, including the relationship between brain and behavior. We present some notes on the concept of behavior, based on documents related to two Brazilian scientists identified as behavioral neuroscientists: Miguel Rolando Covian (1913-1992) and César Timo-laria (1925-2005). These neuroscientists used the concept of behavior in their debates about the connections between the nervous system and the environment. This use was influenced by physiological - especially neurophysiological - and experimental psychological studies. Describing and analyzing such documents and their authors, helps us to understand aspects of the history of neurosciences in Brazil during a period in which neuroscience was spreading rapidly in different countries.
\end{abstract}

Keywords: history of science, history of psychology, history of neurosciences, neurophysiology, experimental psychology

\section{Resumo}

Pesquisas em história das neurociências no Brasil têm focado diferentes aspectos, incluindo a relação entre cérebro e comportamento. Apresentamos notas sobre o conceito de comportamento, baseado em documentos de dois cientistas brasileiros identificados como neurocientistas comportamentais: Miguel Rolando Covian (1913-1992) e César Timo-laria (1925-2005). Esses neurocientistas utilizaram o conceito de comportamento em seus trabalhos sobre as conexões entre o sistema nervoso e o ambiente. Tal uso tinha influências da fisiologia - especialmente da neurofisiologia - e de estudos em Psicologia Experimental. A descrição de tais documentos e de seus autores nos auxiliam a compreender aspectos da história das neurociências no Brasil em um momento em que as neurociências se espalhavam fortemente ao redor do mundo.

Palavras-chave: história das ciências, história da psicologia, história das neurociências, neurofisiologia, psicologia experimental

\section{Resumen}

Las investigaciones en la historia de las neurociencias en Brasil se han centrado en diferentes aspectos, incluida la relación entre cerebro y comportamiento. Nosotros presentamos apuntes sobre el concepto de comportamiento, de conformidad con documentos de dos cientistas brasileños identificados como neurocientistas comportamentales: Miguel Rolando Covian (1913-1992) y César Timo-laria (1925-2005). Eses neurocientistas utilizaron el concepto de comportamiento en sus trabajos sobre las conexiones entre el sistema nervioso y el ambiente. Dicho uso tenía influencias de la fisiología - especialmente de la neurofisiología - y de estudios en Psicología Experimental. Las

\footnotetext{
${ }^{1}$ Research developed during the post-doctoral position of the first author under the supervision of the second one at the Universidade de São Paulo (USP). Grant from the Fundação de Amparo à Pesquisa do Estado de São Paulo (FAPESP).

${ }^{2}$ Contact address: Programa de Pós-Graduação em Psicologia, Universidade Católica Dom Bosco - Av. Tamandaré, 6000, Jardim Seminário, Campo Grande, MS, CEP 79117-900, Tel.: (67) 3312-3605. E-mail: rlmiranda@ucdb.br
} 
descripciones de tales documentos y de sus autores nos ayudan a comprender aspectos de la historia de las neurociencias en Brasil en un momento en que las neurociencias se extendían fuertemente alrededor del mundo.

Palabras clave: historia de las ciencias, historia de la psicología, historia de las neurociencias, neurofisiología, psicología experimental

We present some notes on the concept of behavior based on documents related to two Brazilian neurophysiologists, Miguel Rolando Covian (1913-1992) and César Timo-laria (1925-2005). The main methodological axis is the notion of biography of scientific objects, based on historical and sociological perspectives (Daston, 2000), as seen in the histories of psychology and neuroscience (Danziger, 1997, 2003; Vidal, 2005, 2009). Considering such methodological perspective, scientific objects refers to areas of phenomena that become the subject of scientific research. For example, one can consider intelligence, memory, self, awareness, and also behavior. This sort of history shows the circulation of behavior as a scientific object in other sciences than psychology and not necessarily into the Brazilian behavior analysis' community.

We have used published and unpublished primary sources produced by Covian and Timolaria. These two scientists were chosen because they are key figures in Brazilian behavioral neurosciences (Ventura, 2010). We attempted to understand what was considered "behavioral" by neurophysiologists working on brain-behavior issues in a moment when behavior was circulating in Brazil as a psychological object related to behavior analysis (the 1960s to 1980s). A biography of behavior based on the perspective presented by these two authors allows us to observe a particular case of it as a scientific object, different from that under construction in Brazilian psychology in the same period.

This article is organized into five sections: (a) an expanded picture of Brazilian physiology; (b) a specific context, the Brazilian educational milieu at that time; (c) the example of behavior as an object shared by physiology and psychology in Brazil; (d) the backgrounds of Covian and Timo-laria, and (e) the use of the concept of behavior in their work. Through this, we assess some aspects of neurophysiology in Brazil that contribute to the history of neurosciences in that country as well as to the contemporary debate on the concept of behavior.

\section{Big Picture: Physiology and Neurophysiology in Brazil}

Schwartzman (1979) drew a timeline of publication and institutionalization of science since the colonial period (1500-1815) in Brazil. However, there was a greater investment in the process of scientific research and institutionalization of science from the $19^{\text {th }}$ century onwards. For instance, in Rio de Janeiro there was the creation of the Museu de História Natural (1818), the installation of the Faculdade de Medicina (1832), and the establishment of the Escola Politécnica (1874). There were examples in other cities as well, such as the Escola de Minas de Ouro Preto (1875, Ouro Preto, Minas Gerais), and the Comissão de Geografia e Geologia de São Paulo (1886, São Paulo, São Paulo). These institutions were important to the development of science in the country, especially for fields as botany, geography, physiology, and engineering. Moreover, they promoted the figure of "scientist" in Brazil (Sá, 2006).

The development of physiology was contemporaneous with that of other sciences (Mendes, 2000). In 1880, the first experimental physiology laboratory in Brazil was established in the 
aforementioned Museu de História Natural in Rio de Janeiro. This laboratory was especially influential in the field of pharmacology, with studies on curare 3 . In 1915 another influential physiology laboratory was opened in the city of Rio de Janeiro, that of the brothers Alvaro and Miguel Ozório de Almeida. This laboratory hosted visits of internationally recognized individuals, such as A. Einstein, H. Piéron, and M. Curie, while producing studies on the metabolic characteristics of different species. This topic was central to the Brazilian political agenda in the transition to the $20^{\text {th }}$ century. In addition to these studies, the Ozório brothers were interested in the brain and nervous system (NS), including decerebration and the association between the NS and labyrinthine reflexes.

Brazilian physiology research was also produced in other cities and states, such as São Paulo. One can stress the role of physicians at the Faculdade de Medicina de São Paulo, founded in 1912, such as Ethocles Gomes taught experimental physiology using the neuromuscular pharynx and Franklin de Moura Campos' study of aspects of the neuromuscular larynx. The production and institutionalization of physiology in the state of São Paulo continued after the creation of the Universidade de São Paulo (USP) in 1934, particularly in the 1960s, in the main campus in São Paulo, and in the Ribeirão Preto campus. In São Paulo, researchers investigated biophysics of cell membranes, neural regulation of digestive secretions, sleep, and brain electrical activity. In Ribeirão Preto, there were studies on the NS involving the hypothalamus, reticular formation, and septal area. Miguel Rolando Covian became a driving force of such work, with other researchers in the Department of Physiology including E. M. Krieger, C. M. Lico, R. F. Marseillan, C. E. Negreiros de Paiva, and C. Timo-laria (Mendes, 2000; Franci, 2002).

\section{Educational Renewal: University Reform and Scientific Development}

From the early decades of the $20^{\text {th }}$ century, three elements indicated "progress" and "modernity" in Brazil: industrialization, scientific development, and educational reform. The urban population expanded after a set of investments in the social space (e.g., public transportation, jobs, buildings etc.), especially in southeastern Brazil. Simultaneously, a movement of funds accumulated by an economic elite and the federal government worked to expand the industrial park. These two axes produced a modernization process that mobilized various social groups, such as the urban middle class.

Educational renewal was particularly linked to the promotion of universities and, consequently, investment in scientific research. Gradually, scientists began presenting themselves as spokespersons for modernization and progress. Science was considered a redeemer for social delays in Brazil because it would promote industrial, urban, and social progress (Schwartzman, 2002). For example, Alberto Carvalho da Silva, Director of the Fundação de Amparo à Pesquisa do Estado de São Paulo (Sao Paulo Research FoundationFAPESP) from 1968 to 1969, said:

There is no doubt that the basic problem of scientific and technical development of the country is training personnel in quality and satisfactory number. . . In modern society,

\footnotetext{
${ }^{3}$ Curare is a bitter resinous substance obtained from the bark and stems of some South American plants. It paralyzes the motor nerves and is traditionally used by some native peoples to poison their arrows and blowpipe darts.
} 
one of the most important functions of universities is the training of these scientific personnel. . . (Carvalho da Silva, 1969, p. 9-10)

According to Motta (2014), the university reform that took place in the 1960s resulted in several changes, such as pursuit of efficiency in the management of the university, expansion of places for students, organization of teaching careers, creation of departmental systems, strengthening of research and graduate programs, etc. A consequence of such changes was the promotion of the Brazilian scientific community, which was also influenced by international investments, including from the United States of America (USA). An example of these investments was the Brazilian Ministry of Education (MEC)'s agreements with the United States Agency for International Development (USAID), which had been taking place since the early 1950s and intensified after 1965, influencing the educational renewal and university reform of the period.

Covian and Timo-laria provide examples of this investment. In their papers, we see funding from different agencies, such as FAPESP, the Rockefeller Foundation, and the United States Air Force. Another example of university reform and expansion is the creation of the Faculdade de Medicina da Universidade de São Paulo, Campus Ribeirão Preto (FMRP-USP) in 1952. Its mastermind and first director, Zeferino Vaz, was one of the Brazilian scientists invested in the training of scientists. In his words: "We must never lose sight of the dual purpose of a university institute: the preparation of high-level professionals and the progress of science through original research. .." (1951, cited by Ferraz, 2005, p. 75). Vaz designed FMRP-USP as a venue for the develo pment of original research that would provide highlevel training of students. Research was also a crucial point in the selection of teachers.

\section{Circulating the Object: Behavioral Context in Brazil}

According to Danziger (2003), behavior began to be adopted as a scientific object by those who worked with comparative psychology and social sciences in the early $20^{\text {th }}$ century in anglophone countries (e.g., England, USA). We note behavior was present in different psychologies and popular culture, particularly in the USA (Rutherford, 2009), such as B. F. Skinner and his behaviorism and C. Richter and the specific appetite. Although there is no evidence that behavior held similar fascination as in the USA, it appeared as a psychological object in Brazil in the 1930s. Cirino, Miranda, Cruz, and Araujo (2013) showed that behavioral concepts, with reference to I. P. Pavlov and especially J. B. Watson, already circulated among educators interested in psychology, for example. Between 1950 and 1970, Brazil became a fertile ground for behavior as a psychological object because of the 1930s' legacy and the strengthening of the dialogue with the US scientific community. The USA's influence was expanding around the world, including Latin America, after World War II, and Brazil was concerned with educationespecially higher and university education and- and scientific development.

An example of this expansion was the beginning of the institutionalization of behavioral analysis in the 1960s (Cirino, Miranda, \& Cruz, 2012), with the visits of Fred Keller and the circulation of Skinner boxes as some of the main vectors. This example also indicates a relationship between physiology and psychology in Brazil. Keller was invited by Paulo Sawaya to come to Brazil for a sabbatical between 1961-1962, and in 1961, Keller established a Behavior Analysis Laboratory in the Department of Physiology of the Faculdade de Filosofia, Ciências e Letras of the USP São Paulo Campus (FFCL-USP). During this period, Sawaya was the director 
of FFCL-USP and is considered one of the pioneers in physiology at USP due to its lessons since 1939 (Mendes, 2000). He also worked on comparative pharmacology, ecology, and ethology; in this last field, he collaborated with the Canadian social psychologist O. Klineberg. In a book chapter titled Animal Psychology, Sawaya addressed issues in experimental psychology, mentioning Pavlov as well as E. Thorndike (Sawaya, 1953). After Keller's return to the USA, some of his Brazilian students continued the circulation of behavior as an explanatory category, particularly as operant behavior. This involved teaching experimental psychology, producing technologies of teaching - such as the Personalized System of Instruction (PSI), and researching primarily applied themes (e.g., teaching infants, reading, and writing) (Souza Júnior, Miranda, \& Cirino, 2018; Torres, 2018). Therefore, the Brazilian community of behavior analysts, in those days, seemed to be uninterested in the relationship between brain and behavior.

Those interested in education and the interface between physiology and psychology also discussed the concept of behavior as a scientific object in Brazil. Debates on behavior and its relationship with learning and consciousness occurred in the field of neurophysiology and other biological sciences. For instance, in 1976, at the $38^{\text {th }}$ Annualeeting of the Sociedade Brasileira para o Progresso da Ciência, there was a symposium on learning and consciousness. This symposium addressed behavior as a key concept in physiology, especially for comprehension of aspects of the dichotomy between reductionism and dualism in biological explanations (Chagas Filho, 1977). One of the speakers at this meeting was César Timo-laria. Behavior was also discussed as a scientific object in neurophysiology at FMRP-USP at that time.

\section{Authors}

Miguel Covian and César Timo-laria are good examples for observing the biography of behavior as a scientific object in Neurophysiology. They are recognized as two key figures in the development of physiology, especially neurophysiology in Brazil (Antunes-Rodrigues, Franci, \& Salgado, 2000; Mendes, 2000). Due to their research in neurophysiology, they are also key characters for the development of neurosciences in Brazil, particularly behavioral neurosciences (Graeff, 2014; ; Ventura, 2010). The renowned Argentine-Brazilian scientist I. Izquierdo interned in their laboratory in the late 1950s, for instance (Izquierdo, 2011). Further, due to their interest in research, they are representative of the new teaching model under development in Brazil in that period. A model in which there are full-time professors connected to teaching and researching. Thus, they can help us understand dialogues between physiology and psychology addressing behavior in Brazil.

\section{Miguel Rolando Covian (1913-1992)}

Covian was born in 1913 in Argentina and became a naturalized Brazilian citizen in 1971. He studied at the Facultad de Medicina - Universidad de Buenos Aires (UBA) from 1935-1942 and got his PhD in 1943 under the supervision of Nobel Prize recipient Bernardo Houssay. From 1945 to 1948, Covian worked at the Instituto de Biologia y Medicina Experimental (IByME) in Buenos Aires, which was coordinated by Houssay. Other important physiologists were professors at the IByME - such as Eduardo Braun-Menéndez - who also had influences

${ }^{4}$ Personal communication, October 29, 2014 
on Covian's proposals. However, according to Hoffmann (2005), Covian recognized Houssay as "his master for the whole life" (p. 39).

In 1949, he moved to the USA to pursue his postdoctoral studies at Johns Hopkins University. Awarded a Rockefeller fellowship, he worked in psychobiology and neurophysiology there from 1949-1951, under the supervision of C. Richter and P. Bard. About this period, Covian (1972) stated

When we began our scientific career, despite our vocation for neurophysiology and in the absence of those who supervises us in this discipline, we conducted our first research work on existing themes in the laboratory where we did our first steps. At this early stage, however, already we excursion into psychobiology. . . . After our training in the USA, our research activity was devoted entirely to the field of neurophysiology (p. 30).

At the junction between psychobiology and neurophysiology, Covian met conditions for his scientific development.

In 1949, he returned to Buenos Aires to establish Argentina's first neurophysiology laboratory at the IByME. The 1950s was a decade of strong economical, political and ideological crisis in Argentina that affected several areas, like scientific communities (Hurtado, 2010). About this, Covian affirmed: "Our future was not clear, as if there was a wall blocking our way" (Covian, 1979, p. 615). In this same year, Zeferino Vaz- dean of the FMRP-USP- invited him to become the chair of the Physiology Department. Covian's research affected diverse areas of research at the FMRP-USP, such as brain cortex control of autonomic functions, the role of NS structure in metabolism, brain areas related to water and sodium intake, and neuroendocrine regulation (Antunes-Rodrigues, Franci, \& Salgado, 2000).

\section{César Timo-laria (1925-2005)}

César Timo-laria was born in Sao Paulo state and earned a degree in Medicine from the Escola Paulista de Medicina (EPC), São Paulo, Brazil (1947-1952). In 1953, he and several colleagues were involved in the initial organization of the Physiology Department of the FMRPUSP; he became an instructor there. He was awarded his PhD under Covian's supervision in 1961, with a dissertation entitled Efeitos da estimulação da formação reticular mesencefálica sobre reflexos monossinápticos espinais. Timo-laria worked as a physiology professor at the FMRP-USP from 1961 to 1964, when he moved to the USP's main campus in São Paulo. In 1962, he performed research at the Instituto de Investigaciones Cerebrales, Tlaplan city, Mexico. This was an influent experience that introduced him to other neurophysiological and psychophysiological researchers who used the concept of behavior in their practices, such as R. Hernandez-Peón, G. Chavéz-Ibarra, and P. J. Morgane.

$\mathrm{He}$ is recognized for his contributions in the study of the neural regulations of digestive secretions and sleep (Mendes, 2000). Sleep was one of his main topics of research with his international colleagues. In this topic, he was one of the first researchers to use electroencephalography in Brazil and his laboratory at FMRP-USP performed some of the first records of experimental sleep in cats in Latin America (Antunes-Rodrigues, Miglirorini, \& Krieger, n.d.). 


\section{Behavior: Describing and Analyzing its use by Covian and Timo-laria}

Covian and Timo-laria were neurophysiologists interested in the central nervous system (CNS), particularly brain function and its relationship with behavior. A FMRP-USP student at that time described the laboratory's focus as ". . . neurological aspects, aspects of animal behavior. . . as a brain function, animal behavior under different stimuli . .." (M. E. H. D. Yazlle, personal communication, February 26, 2015). This also related to the intellectual ambience of Brazilian physiology at that time. According to Mendes (2000), in the 1960s, physiology could be defined as

The analysis of the living behavior, the study of phenomena presented by living organisms, their classification and recognition of their sequence and relative significance, assigning each function to its proper biological organ and the study of the conditions that determine each function. (p. 7)

Covian and Timo-laria's prevailing method utilized animal-based experimentation with cats and rats. They used a variety of laboratory equipment, such as oscilloscopes, stereotaxic instruments, electronic stimulators, pneumographs, and polygraphs, and frequently included electrical or chemical stimulation with different drugs, such as cholinergic and adrenergic agents, or electrolytic lesion of limbic brain areas including the amygdala, hypothalamus, and septal area.

According to Damasceno (2013), Covian defined his main neurophysiological research interest as "the brain-mind interaction." Behavior appeared to mediate that interaction, especially feeding and emotional behaviors. Covian's private library held many examples of books on the brain-mind-behavior relationship (Table 1).

Table 1

Covian's private library

\begin{tabular}{cll}
\hline $\begin{array}{c}\text { Year of } \\
\text { publication }\end{array}$ & \multicolumn{1}{c}{ Author } & \multicolumn{1}{c}{ Title* } \\
\hline 1927 & I. P. Pavlov & Conditioned Reflexes \\
1929 & I. P. Pavlov & Lessons on the Cerebral Cortex Activity \\
1947 & C. S. Sherrington & The Integrative Action of Nervous System \\
1949 & R. Woodworth & Experimental Psychology \\
1955 & I. P. Pavlov & Conditioned Reflexes Applied to Psychopathology and Psychiatry \\
1959 & E. A. Asratian & Lectures on Certain Neurophysiological Questions \\
1960 & D. O. Hebb & Behavioral Psychology \\
1961 & N. Tinbergen & Social Behavior in Animals \\
& O. L. Zangwill & $\begin{array}{l}\text { Cerebral Dominance and Its Relation to Psychological Function } \\
\text { Conditioning }\end{array}$ \\
1962 & I. M. Sechenov & Selected Physiological and Psychological Works \\
1963 & D. O. Hebb & Organization of the Behavior \\
& K. Lashley & Brain Mechanisms and Intelligence \\
1965 & I. M. Sechenov & Reflexes of the Brain \\
1968 & P. K. Anokhin & Internal Inhibition as a Physiological Problem \\
\hline
\end{tabular}

* Titles in other languages (e.g., French, Spanish, and Russian) were translated into English 
Several of the listed authors were influential in the development of the concepts of behavior and reflex as scientific objects, including Sechenov, Sherrington, and Pavlov (Pessotti, 1976). In addition to this, the brain-mind-behavior relationship was a key theme in Covian's lectures, didactic texts, and scientific articles (Covian, 1969, 1960, 1961a). Some of these concepts appear in his papers, including those of Pavlov (Lico, Hoffmann, \& Covian, 1974), Sherrington (Covian, 1969) and Woodworth (Covian, 1969).

Timo-laria was also interested in the relationship between the brain and mind, as seen in his conferences, didactic publications, and unpublished texts (Timo-laria, 1977, 1980, 1985). For example, in a letter addressed to a colleague at FMRP-USP, he discussed what he felt was a key problem in neurophysiology, the use of the phrase "physiology and behavior" (Timo-laria, 1980). According to Timo-laria, behavior was a physiological object, and therefore, there was no need to use the conjunction 'and.' In his own words:

It is customary to separate the study of the behavior from physiology, which is incorrect. Most of the vast ranges of basic phenomena that occur in animal organisms have the penultimate purpose, enable and build behavior. Behaviors enable and maintain the basic phenomena ... and help to achieve the ultimate goal, which is to maintain the living organism. (Timo-laria, 1985, p. 163)

In Timo-laria's analysis, behavior maintain homeostasis, which in turn supports other behaviors. This justifies behavior as a physiological scientific object particular to neurophysiology. Later on, he wrote

. . The history of neurophysiology is intertwined with the history of physiology is [because] the whole function of the organism, from the invertebrate to the more evolved vertebrate, for now Homo sapiens, is generated, regulated or modulated by nervous system. (Timo-laria, 2000, p. 54)

As we could see, they were interested in how the NS generates, regulates, and modulates physiological functions in combination with the environment. Behavior was phenomena generated, regulated, and modulated by the NS, appearing as a manifestation of organic functioning due to environmental changes and mediating organism-NS-environment interaction. Covian and Timo-laria were interested in behavior in a broader and more complex way than the Brazilian behavioral analysts at the time.

According to Covian (1969), "The whole organism interacts with the environment through its behavior. Consequently, the organism adjusts functions to this interaction" (p. 1167). In another part of this same text, he stated:

Internal modifications - metabolic or hormone - cause rhythmic or periodical changes in behavior. These homeostatic changes drive the animal to satisfy its organic necessity in the environment. Activities produced by those changes appear as an extension of organic regulation ... (Covian, 1969, p. 1174)

Timo-laria had similar ideas about behavioral manifestations as consequences of organic changes. In an unpublished text, he stated:

[The] nervous system's basic functions can be summed up into two classes: 1. Regulation of specific mechanisms that maintain the intrinsic stability on the body, preventing the 
disruption of basic vegetative functions. . ; 2. Survival of the organism as an individual and specie. . . . Functions that create living conditions for the body interact with the environment- as an individual and as a specie- are performed by behaving. (Timo-laria, n.d., p. 3-4)

Put simply, one of the NS's functions is to produce behaviors that mediate the biologically important interaction between organism and environment. This perspective seems to have been influenced by the readings and previous experiences of Timo-laria and Covian. On one hand, this combination of elemental aspects with a generalized use of behavior (behavioral manifestation) can be found in Sherrington and Bard's perspectives. Sherrington was influential in physiology, especially in behavioral studies, and Bard followed Covian closely during his postdoctoral fellowship. Conversely, Houssay's proposals in physiology were also influential in Latin American physiology. Houssay had a holistic approach to physiological themes, considering the whole organism as a functional unit (Cueto, 1994), a perspective that also appears in Timo-laria and Covian's writings.

Covian and Timo-laria's work frequently involved the link between specific brain regions and behavior. One often sees the following question: "What are the structures responsible for. . .?" (Covian, 1961b). What the ellipsis represented varied, including blood pressure, drinking behavior, lever pressing, and other processes. In this context, behavior was another object for which a structure needed to be found to explain it - especially in the NS- to connect the NS and behavior. For instance, "The limbic system is the other section of the brain that in the last years has called the attention of many laboratories because of its influence on behavior and neurovegetative functions" (Covian, Antunes-Rodrigues, \& Mendonça, 1962, p. 115). Their research included the limbic system because it was related to behavior. It also suggests that these Brazilian authors were interested in mapping the connections between brain and behavior onto specific areas. Timo-laria gives a clear example of this biological reductionism:

Although from all these areas behavioral manifestations of rage were obtained including growling, hissing, motor effects (retraction of the ears, striking, and biting) and autonomic effects (mydriasis and piloerection), the animal only directed his attacks when stimulated in the forebrain areas. (Hernandéz-Peón, Chavez-Ibarra, Morgane, \& Timo-laria, 1963, p. 103)

These two primary sources - especially the latter one - show that behavior was a scientific object due to its relationship to bodily functioning and NS activities. Covian and Timo-laria both used "behavior" and "behavioral manifestation" as synonyms to refer to behavioral events linked to physiological and environmental stimuli. Behavior, from their perspectives, was a consequence or manifestation of brain stimulation, as described by the rage manifestations quoted above.

Covian and Timo-laria were aware of a sort of debate about the definition of behavior and how behavior was connected to the NS (Covian, 1961b, 1969; Timo-laria, n.d., 1985). According to them, the debate on behavior occurred due to many factors, such as its origins as a mankind concern, and its determinations. Covian (1961b) explained that behavior was a longstanding concern of mankind in respect of its manifestations and its causes. There were several different explanations and concepts among a variety of scientific areas, such as psychology and physiology. Timo-laria (1985) affirmed: "The concept of behavior is 
plural. According to some authors, this term is used only for bodily manifestations related to mental activity; for others, behavior could be just integrated activities in the brain or conscious acts" (p. 163). Some of their evidence was from psychology, and some was experimental psychology. They referred to B. F. Skinner, C. Richter, C. S. Sherrington, E. L. Thorndike, I. P. Pavlov, J. Olds, K. Lorenz, P. Bard, and W. Woodworth. Some of these authors appeared in Covian's private library (Table 1), and others in Covian and Timo-laria's writings (see Covian, 1961b; Timo-laria, 1985). The debate on a definition of behavior by Brazilian physiologists was also related to the relationship between brain and consciousness (Chagas Filho, 1977). For some Brazilian researchers, behavior and consciousness were determined by brain structures and by chemical modulations. For others - particularly influenced by Sherrington's perspectives - behavior and consciousness were aspects that emerge from the relationship between the whole organism and environment. This second perspective seems to have affected some members of Covian's lab. For example, while researching on pain, they stated: "Nevertheless, pain is not a mathematical function of the amount of bodily damage. Previous experience, environmental situation, the significance of pain, and culture play an important role in the perception of pain's intensity and quality" (Lico, Hoffmann, \& Covian, 1974, p. 805). It means that behavior has several determinants.

They often used concepts related to experimental psychology in their papers, including classical (reflex) and operant (instrumental) conditioning, and frequently quoted Pavlov and his students Anokhin and Asratian. The concept of a conditioned reflex was part of Covian and Timo-laria's interest in NS plasticity. According to Covian (1969): "Conditioned reflexes are based on the plasticity property of nervous system whose method was developed by Pavlov... one of the greatest advances of modern physiology" (p. 177). Their use of the reflex concept can be identified in their publications by the use of the verb "to elicit" in relation to the behavior being focused upon. For instance, "These changes [blood and respiratory] were elicited only during stimulation" (Covian, Lico, \& Antunes-Rodrigues, 1966, p. 100, italics added). They also wrote, "In the course of this research, other behavioral as well as motor and autonomic effects were elicited from many brain loci following cholinergic and adrenergic stimulation" (Hernandéz-Peón et al., 1963, p. 95, italics added). Eventually, the concept of a conditioned reflex was clearly stated: "Establishing reflexes by the association of pain with other stimuli produces an escape reaction" (Covian, 1965, p. 144, italics added). These excerpts suggest the impact of Pavlov and his intellectual descendants, and of the substitutive stimulus method related to classical conditioning. Observing responses such as an escape reaction could indicate other aspects of the brain-behavior relationship. Although their main focus was NS activity, their analysis could include external events as well. This sort of observation and analysis appeared repeatedly (Schmidek, Hoshino, \& Timo-laria, 1972).

Operant behavior was also referenced, although sometimes Covian and Timo-laria called it "operant" and sometimes "instrumental." Their usage of this concept originated with E. L. Thorndike and B. F. Skinner. For example,

Skinner defines behavior as 'what an organism is doing or, more accurately, what an organism sees as the action of another organism.' Despite being stated in an unconventional way, this concept is what comes closest to a satisfactory definition. . . (Timo-laria, 1985, p. 163) 
In 1969, Covian explained conditioned reflexes and referred to both conditioning types, I and II, and to the concept of behavior as stated in Skinner's book The Behavior of Organisms. He affirmed: "In Type I (pavlovian) reinforcement is the unconditioned stimulus; in Type II is the punishment or the reward" (p. 1182). Seem they may have approached physiology and behavior in a manner similar to Skinner's $(1931,1935)$. Operant behavior was also clearly used in some of their publications coauthored by psychology-based researchers (Graeff, Gentil, Peres, \& Covian, 1973). The experimental design of the Graeff study was very similar to those used in the experimental analysis of behavior, including the use of schedules of reinforcement. In addition, the authors used an operant conditioning chamber and a cumulative recorder, though these pieces of equipment appear to be appropriated as resources, rather than used as the experimental basis to fulfill a theoretical perspective:

In addition, present results suggest that the use of operant behavior techniques may provide a better method to assess the motivational effect of angiotensin, than the currently used, amount of water consumed method . . . In contrast, with operant procedures, the amount of water ingested after angiotensin can be reduced to a minimum, by the use of intermittent schedules of reinforcement, in which only a fraction of the total number of responses are followed by water presentation. (Graeff, 1973, p. 358)

Behavioral analysis was a tool for the investigation of NS activity. According to Timo-laria (1985): “. . . operant conditioning is based on temporal contingency established between a neural action (a motor adjustment reflex or vegetative) and a stimulus (p. 177)". That is, operant behavior - as a type of behavior - appeared as a result of the interaction between brain and environment. This sort of approach was different from Brazilian behavior analyst experimental research from the 1960s to the 1980s, considering its focus on basic principles and applied behavior analysis (e.g., Azzi, Fix, Keller, \& Rocha e Silva, 1964; Majias, 1976).

Timo-laria and Covian's uses of operant conditioning and Skinnerian techniques can also be understood through other references. For instance, they often mentioned Olds' investigations using operant conditioning boxes and cumulative recorders (Olds \& Milner, 1954; Olds, 1958), in particular while discussing self-stimulation and reward. However, Olds' interest was in mapping brain areas related to the reinforcement process, and not on the schedules of reinforcement. In his studies, stimulation was carried out by means of chronically implanted electrodes in rats. Each rat was tested in an operant cage, which delivered alternating current to the brain as long as the lever was depressed. His results illuminated reward, punishment, and neutral areas of the brain that correlated with the rat's cumulative response. Covian (1961b) affirmed, "Technical elements produced by Olds allowed a series of psychological investigations. For example, we can measure stimulation on rat's brain as a reward to face aversive situations" (p. 199). Covian and Olds used the word "reward" as a synonym for "reinforcement." Once again, operant behavior techniques were used as resources for brain studies. Covian and Timo-laria also pointed out some results of physiological research that could be analyzed via psychological means. This appeared in Covian's reading on Olds' techniques, as well as in other papers. In 1967, Covian stated: "These and other questions involving neurophysiological and even psychological implications claim clarification" (p. 210). Another example, from a study on evoked potentials, reads: "The activity of the sensory system is subject to modification by central regulation mechanisms 
and background states, sufficiently pronounced to be capable of influencing perception and so to be of interest for psychology" (Covian, Timo-laria, \& Marseillan, 1961, p. 441, italics added). Some issues they addressed could thus have implications for psychology research, especially as related to neurophysiology.

Covian and Timo-laria also used the terminology of classical and operant conditioning. This was not just the words alone, such as "to reinforce," but reflected their use of classical and operant conditioning as a unit. Timo-laria (1985) described both concepts: "Pavlovian conditioning is a reflex response associated to a second (conditional) stimuli. Operant conditioning is an action that would not occur casually that is associated to a conditional stimulus" (p. 177). He suggested the stimulus-response relationship differed significantly. In classical conditioning, the relationship is natural (casual), whereas in the operant one, it is arbitrary (non-casual). It appears that this use of the word "natural" was related to the phylogenetic origins of the reflex. The arbitrariness of operant behavior affected its connection with the consequence. The non-casual property of reinforcement was even criticized from a methodological standpoint: "In some cases it is easy to admit that the result of the homeostatic action or conditioned response is a reinforcement; in other situations, the reinforcement properties are difficult to verify" (p. 178). This difficulty was explained by the method of study, observing a behavior and its putative consequence. When applied to the NS, this method could not reliably measure the relationship between brain and behavior, usually due to external, uncontrolled, factors ${ }^{5}$.

Finally, Covian and Timo-laria also blended classical and operant behavior. According to Covian (1967):

The regularity and magnitude of the evoked arterial hypotension obtained by septal stimulation led us to test its conditionability. Thus, the unconditioned response elicited by stimulation of the septal area in rabbits under urethane anesthesia was used as a reinforcer of a sensorial (acoustic) stimulus. (p. 205, italics added)

In 1969, Covian explained: "To keep the conditioned response occurring, the conditioned stimulus should be always followed by the unconditioned one, i.e., to be reinforced. In this circumstance, the unconditioned stimulus can be called reinforcement" (Covian, 1969, p. 1179). These excerpts show a particular use of behavior as a scientific concept and indicate a neutral stimulus was described as reinforcement because it acquired conditioned properties due to the pairing of stimuli. When the conditioned stimulus was presented, the conditioned response rate increased. They mixed classical and operant conditioning for their behavioral testing purposes rather than presenting a particular perspective on behavior as a scientific object, a practice that seems to be a distinctive approach to behavior in Brazil at that time. Especially when one compares it to the circulation of behavior among psychologists during the 1960s to the 1980s, particularly tied to behavior analysis and operant conditioning

\footnotetext{
${ }^{5}$ One would assume that this difficulty arises from the incomplete observation of the behavioral context by a restricted implementation of the functional analysis. However, in despite of the study of the concepts of Pavlovian conditioning and operant behavior by Covian and Timo-laria, it is not evident in our primary sources their attachment to the philosophical aspects of the radical behaviorism, that would guide the functional analysis previously mentioned. Therefore, we avoid any interpretation of the lack of any functional analysis by both authors; firstly, because of the absence of sources in this direction and secondly, due to the fact that this could be considered as a sign of whiggishness - or presentism.
} 
concepts. Pavlov used the verb "to reinforce" to refer to the connection between conditioned stimuli and response, but he did not mean the mechanism of reinforcement. Based on this interpretation, when Covian and Timo-laria explained behavior in terms of reinforcement/ reward, they seem not to be using "to reinforce" as Pavlov did. They were appropriating operant and classical conditioning in a particular way that explained differences among those phenomena (Timo-laria, 1985), but blended them into a unit when describing behavior in their research. This was also distinct from Brazilian scientific literature at the time, especially psychological literature. The Brazilian behavioral analysis community used operant and classical behaviors as two different phenomena and gave them different names. Covian and Timo-laria blended what seemed to be two different processes into a distinctive unit.

\section{Final Considerations}

Our study points out the use of behavior as a scientific object in studies performed by two Brazilian neurophysiologists, Miguel Rolando Covian and César Timo-laria. In their work, behavior was defined as an object of physiology due to its role in mediating the brainenvironment relationship. Their explanations of this relationship were based on a biological reductionism in which behavioral manifestations were correlated with different anatomical and functional aspects of the NS. Some concepts and processes of behavior they employed frequently were highlighted, such as classical (reflex) and operant (instrumental) conditioning. Their work suggests these two concepts could be scientific objects in the contact zones between neurophysiology and experimental psychology in Brazil and helps us understand how they used this blend of experimental psychology and neurophysiology. It is particularly significant that behavior as a scientific object in neurophysiology could be manipulated as a blended unit of classical and operant behavior.

We should also mention some limitations on our perspective. Our intention was to show behavior as a scientific object in other sciences than psychology and not necessarily into the Brazilian behavior analysis' community. We focused on a solid body of work generated by two particular scientists, thus helping us to understand processes of the indigenization of science in Brazil, including how behavior was manipulated in experimental psychology, neurophysiology, and, finally, behavioral neuroscience. Our analysis cannot be extended to the entire historical period under discussion or other Brazilian authors within it. Further analyses should broaden our understanding of the initial steps. For instance, one might analyze how different authors (e.g., B. F. Skinner, C. Richter, C. S. Sherrington, I. P. Pavlov, J. Olds) influenced fields such as experimental psychology, neurophysiology, and behavioral neuroscience. In observing Covian and Timo-laria, one could analyze authorship in their publications as potential starting points of new scientific communities or investigate the material culture and capabilities of the period through their laboratory apparatus and research techniques. Other studies could highlight contributions by other authors whose perspectives may differ from those of Covian and Timo-laria. Here though, we have identified a meaningful pattern associated with the use of behavior as a scientific concept that contributes to a better understanding of the history of experimental psychology, neurophysiology, and behavioral neuroscience in Brazil. 


\section{References}

Antunes-Rodrigues, J., Franci, C. R., \& Salgado, H. C. (2000). Evolução da Fisiologia na Faculdade de Medicina de Ribeirão Preto - USP [Evolution of Physiology at the Faculdade de Medicina de Ribeirão Preto - USP]. In Sociedade Brasileira de Fisiologia (Ed.), Fisiologia no Brasil (pp. 79-112). Ribeirao Preto, SP, Brazil: Sociedade Brasileira de Fisiologia.

Antunes-Rodrigues, J., Migliorini, R. H., \& Krieger, E. M. (n.d.). A família dos fisiologistas brasileiros perde um de seus mais ilustres Mestres: Professor César Timo-laria [The Brazilian family of physiologists loose one of its more famous Masters: Professor César Timo-laria] [Website post]. Retrieved from http://www.sbfte.org.br/profcesar.htm

Azzi, R.; Fix, D. S. R.; Keller, F. S.; \& Rocha e Silva, M. I. (1964). Exterioceptive control of response under delayed reinforcement. Journal of the Experimental Analysis of Behavior, 7(2), 159-162.

Carvalho da Silva, A. (1969). Relatório do diretor científico [Scientific director report]. In Fundação de Amparo à Pesquisa do Estado de São Paulo (Ed.), Relatório das atividades 1968 (pp. 8-13). Available in http://www.fapesp.br/publicacoes/

Chagas Filho, C. (Ed.). (1977). Ciência e consciência [Science and consciousness]. Rio de Janeiro, Brazil: Tempo Brasileiro.

Cirino, S. D., Miranda, R. L., \& Cruz, R. N. (2012). The beginnings of Behavior Analysis in Brazil: A pedagogical view. History of Psychology, 15(3), 263-272. doi: 10.1037/a0026306

Cirino, S. D., Miranda, R. L.; Cruz, R. N., \& Araujo, S. F. (2013). Disseminating behaviorism: The impacts of J. B. Watson's ideas on Brazilian educators. Revista Mexicana de Análisis de la Conducta, 39(2), 119-134.

Covian, M. R. (1960). Sistema nervioso central y comportamiento [Nervous system and behavior]. Paper presented at the Sesiones Cientificas de Biología, Mendonza, Argentina.

Covian, M. R. (1961a). Comportamento e sistema nervoso [Behavior and nervous system]. Revista Paulista de Medicina, 58, 53-57.

Covian, M. R. (1961b). Neurofisiologia [Neurophysiology]. Unpublished material, Serviço de Neurologia, Faculdade de Medicina da Universidade de São Paulo, Ribeirão Preto, São Paulo, Brazil.

Covian, M. R. (1965). Fisiopatogênese da dor [Physiopathogenesis of pain]. Arquivos de Neuro-Psiquiatria, 23(3), 143-164.

Covian, M. R. (1967). Studies on the neurovegetative and behavioral functions of brain septal area. Progress in Brain Research, 27, 189-217.

Covian, M. R. (1969). Sistema nervioso [Nervous system]. In R. Caldeyro-Barcia, M. R. Covian, J. C. Fasciolo, V. G. Foglia, A. B. Houssay, E. Hug, L. F. Leloir, J. T. Lewis, \& L. Soldati (Eds.), Fisiologia humana (pp. 879-1293). Buenos Aires, Argentina: El Ateneo. Originally published in 1945.

Covian, M. R. (1972). Memorial [Memorial] Miguel Rolando Covian Archives, Museu da Faculdade de Medicina de Ribeirão Preto, Espaço Cultural e de Extensão Universitária, Universidade de São Paulo, Ribeirão Preto, SP.

Covian, M. R. (1979). A essência da universidade [The Inwardness of the University]. Ciência e Cultura, 31(6), 615-620. 
Covian, M. R.; Timo-laria, C,. \& Marseillan, R. (1961). Changes in cortical evoked potentials by previous reticular stimulation. In J. F. Delafresnaye (Ed.), Brain mechanism and learning: $A$ symposium (pp. 433-444). Oxford, UK: Blackwell Scientific Publications.

Covian, M. R., Antunes-Rodrigues, J., \& Mendonça, D. V. (1962). Influence of limbic system on blood pressure and respiratory response in the rat. Acta Physiologica Latino Americana, 12, 115-121.

Covian, M. R., Lico, M. C., \& Antunes-Rodrigues, J. (1966). Blood pressure and respiratory changes by stimulation of brain septal area in rats. Acta physiologica latino Americana, 16(2), 99-105.

Cueto, M. (1994). Laboratory styles in Argentine Physiology. Isis, 85(2), 228-246.

Damasceno, E. N. (2013). Criação do arquivo epistolar do neurofisiologista Prof. Dr. Miguel Rolando Covian: Um registro histórico-contextual [The creation of a epistolary archive of the neurophysiologist Prof. Dr. Miguel Rolando Covian: A historical-contextual record] (Master Thesis, Faculdade de Filosofia, Ciências e Letras, Universidade de São Paulo, Ribeirão Preto, Brazil).

Danziger, K. (1997). Naming the mind: How psychology found its language. London, United Kingdom: Sage.

Danziger, K. (2003). Wheretheory, historyand philosophy meet: The biography of psychological objects. In D. B. Hill, \& M. J. Kral (Eds.), About psychology: Essays at the crossroads of history, theory and philosophy (pp. 19-33). New York, NY: New York University Press.

Daston, L. Introduction (2000). In L. Daston (Ed.), Biographies of scientific objects (pp.1-14). Chicago, IL: University of Chicago Press.

Ferraz, J. B. F. (2005). Faculdade de Medicina de Ribeirão Preto - USP: Criação e impacto no ensino médico [Faculdade de Medicina de Ribeirão Preto - USP: Creation and impact on medical training]. Ribeirão Preto, SP, Brazil: FUNPEC.

Franci, C. R. (2002). Departamento de Fisiologia [Physiology Department]. Medicina, Ribeirão Preto, 35(3), 277-283.

Graeff, F. G., Gentil, C. G., Peres, V. L., \& Covian, M. R. (1973). Lever-pressing behavior caused by intraseptal Angiotensin II in water-satiated rats. Pharmacology Biochemistry and Behavior, 1(3), 357-359.

Hernandéz-Peón, R., Chavez-Ibarra, C., Morgane, P. J., \& Timo-laria, C. (1963). Limbic cholinergic pathways involved in sleep and emotional behavior. Experimental Neurology, 8(2), 93-111.

Hoffmann, A. (2005). Resgate da memória de uma experiência universitária: A história de Miguel Rolando Covian [Memories of an University Experiency: The history of Miguel Rolando Covian]. Resumo de trabalho apresentado no I Congresso Paulista de Medicina. Ribeirão Preto, São Paulo, Brazil.

Hurtado, D. (2010). La ciencia Argentina, Un Proyecto Inconcluso: 1930-2000 [Argentinian Science: An unfinished project: 1930-2000]. Buenos Aires: Edhasa.

Izquierdo, I. (2011). Ivan Izquierdo. In L. R. Squire (Ed.), The history of neuroscience in autobiography (vol. 7, pp. 188-230). New York, NY: Oxford University Press.

Lico, M. C., Hoffmann, A., \& Covian, M. R. (1974). Influence of some limbic structures upon somatic and autonomic manifestations of pain. Physiology and Behavior, 12(5), 805-811. 
Majias, N. P. (1976). A análise do comportamento aplicada à escola [Behavior analysis applied to school]. Modificação do Comportamento: Pesquisa e Aplicação, 1(1), 41-50.

Mendes, E. G. (2000). História da Fisiologia no Brasil [History of Physiology in Brazil]. In Sociedade Brasileira de Fisiologia (Ed.), Fisiologia no Brasil (pp. 7-30). Ribeirão Preto, SP, Brazil: Sociedade Brasileira de Fisiologia.

Motta, R. S. P. (2014). As universidades e o regime militar [Universities and military regime]. Rio de Janeiro, Brazil: Zahar.

Olds, J., \& Milner, P. (1954). Positive reinforcement produced by electrical stimulation of septal area and other regions of the rat brain. Journal of Comparative Physiology and Psychology, 47(6), 19-27.

Olds, J. (1958). Selective effects of drives and drugs on "reward" systems of the brain. In G. E. W. Wolstenholme \& C. M. O'Connor (Eds.), Neurological bases of behavior (pp. 124-141). Boston, MA: Little, Brown and Company.

Pessotti, I. (1976). Pré-história do condicionamento [Pre-history of conditioning]. São Paulo, Brazil: HUCITEC-EDUSP.

Rutherford, A. (2009). Beyond the box: B.F. Skinner's technology of behavior from laboratory to life, 1950s-1970s. Toronto, Canada: University of Toronto Press.

Sá, D. M. (2006). A ciência como profissão: Médicos, bacharéis e cientistas no Brasil (18951935) [Science as a profession: Physicians, bachelors, and scientists in Brazil (1895-1935). Rio de Janeiro, Brazil: Fiocruz.

Sawaya, P. (1953). Psicologia animal [Animal psychology]. In O. Klineberg (Ed.), A psicologia moderna (pp. 101-131). São Paulo, Brazil: Agir.

Schmidek, W. R., Hoshino, K., \& Timo-laria, C. (1972). Influence of environmental temperature on the sleep-wakefulness cycle in the rat. Physiology and Behavior, 8(2), 363-371.

Schwartzman, S. (1979). Formação da comunidade científica brasileira [The constitution of scientific community in Brazil]. São Paulo, Brazil: Companhia Editora Nacional and Finep.

Schwartzman, S. (2002). Um espaço para a ciência: A formação da comunidade científica no Brasil [A space for Science: The constitution of the Brazilian scientific community]. (S. Bath and O. Biato, Trans.) Available in http://www.schwartzman.org.br/simon/spacept/ espaco.htm

Skinner, B. F. (1931). The concept of reflex in the description of behavior. Journal of General Psychology, 5, 427-458. doi: 10.1080/00221309.1931.9918416

Skinner, B. F. (1935). Two types of conditioned reflexes and a pseudo type. Journal of General Psychology, 12, 66-77. .

Souza Júnior, E. J., Miranda, R. L., \& Cirino, S. D. (2018). A recepção da instrução programada como abordagem da análise do comportamento no Brasil nos anos 1960 e 1970 [The reception of programmed instruction as an approach to behavioral analysis in Brazil in the 1960s and 1970s]. História, Ciências, Saúde - Manguinhos, 25(2), 449-467.

Timo-laria, C. (n.d.) Organização geral do sistema nervoso [General organization of nervous system]. Unpublished manuscript, Departamento de Fisiologia e Farmacologia, Instituto de Ciências Biomédicas, Universidade de São Paulo, São Paulo, São Paulo, Brazil. 
Timo-laria, C. (1977). A consciência como problema biológico [Consciousness as a biological issue]. In C. Chagas Filho (Ed.), Ciência e consciência (pp. 23-55). Rio de Janeiro, Brazil: Tempo Brasileiro.

Timo-laria, C. (1980, October 16). Prezada Maria [Dear Maria]. Copy in possession of Anette Hoffmann.

Timo-laria (1985). Fisiologia e sistema nervoso [Physiology and nervous system]. In M. M. Aires (Ed.), Fisiologia Básica (pp. 22-300). Rio de Janeiro, Brazil: Guanabara Koogan.

Timo-laria (2000). História da Neurofisiologia no Brasil [History of Neurophysiology in Brazil]. In Sociedade Brasileira de Fisiologia (Ed.), Fisiologia no Brasil (pp. 53-60). Ribeirao Preto, SP, Brazil: Sociedade Brasileira de Fisiologia.

Timo-laria, C. (2002, Julho 26). Caríssimos [Dear friends - Letter to his friends on his 78 years old birthday]. Copy in possession of Anette Hoffmann.

Torres, J. A. (2018). Por uma história institucional da Análise do Comportamento no Brasil: Estudos sociobibliométricos (1976-1986) [Toward an institutional history of behavior analysis in Brazil: Socibibliometric studies (1976-1986)]. (Unpublished master's thesis, Universidade Católica Dom Bosco, Campo Grande, Mato Grosso do Sul, Brazil).

Ventura, D. F. (2010). Um retrato da área de neurociência e comportamento no Brasil [A report on the area of neuroscience and behavior in Brazil]. Psicologia: Teoria e Pesquisa, 26(esp.), 123-129. doi: 1590/S0102-37722010000500011

Vidal, F. (2005). Le sujet cérébral: Une esquisse historique et conceptuelle [Brainhood: A historical and conceptual sketch]. Psychiatrie, sciences humaines, neurosciences, 3(11), 37-48.

Vidal, F. (2009). Brainhood, anthropological figure of modernity. History of Human Sciences, 22(1), 5-36. doi: 10.1177/0952695108099133

Recebido em: 11/08/2018

Última revisão: 04/02/2019

Aceite: 27/02/2019

\section{About the authors :}

Rodrigo Lopes Miranda - Professor of the Graduate Program of Psychology at the Universidade Católica Dom Bosco (UCDB). Head of the Working Group on the History of Psychlogy of the Associação Nacional de Pesquisa e Pós-Graduação em Psicologia (ANPEPP) and vice-president of the Brazilian Society for the History of Psychology (SBHP). E-mail: rlmiranda@ucdb.br, Orcid: http://orcid.org/0000-0003-3222-7368

Marina Massimi - Senior Professor of the Instituto de Estudos Avançados (IEA) at the Universidade de São Paulo (USP) in which coordinates the research grup "Tempo, Memória e Pertencimento." Editor of the Memorandum: Memória e História em Psicologia. E-mail: mmassimi3@yahoo.com, Orcid: http://orcid.org/0000-0001-9103-9960

Anette Hoffmann - Senior professor of the Comissão de Cultura e Extensão Universitária of the Faculdade de Medicina de Ribeirão Preto at the Universidade de São Paulo (FMRP-USP). Vice-president 
of the Centro de Memória e Museu Histórico of the FMRP. E-mail: ahoffman@fmrp.usp.br, Orcid: http://orcid.org/0000-0002-3794-0667

Sérgio Dias Cirino - Professor and Head of the Graduate Program of Psychology at the Universidade Federal de Minas Gerais (UFMG). Researcher on Productivity at CNPq - Level 2. E-mail: sergiocirino99@yahoo.com, Orcid: http://orcid.org/0000-0002-5835-0068 